\title{
Sialochemistry of patients with autoimmune rheumatic disease with and without histological manifestations of Sjögren's syndrome
}

\author{
E B TSIANOS, ${ }^{1}$ A G TZIOUFAS, ${ }^{1}$ A K MAVRIDIS ${ }^{2}$ A K SARRAS, ${ }^{1}$ \\ C S PAPADIMITRIOU, ${ }^{3}$ O TSOLAS, ${ }^{4}$ AND H M MOUTSOPOULOS
}

From the Departments of ${ }^{1}$ Medicine, ${ }^{2}$ Microbiology, ${ }^{3}$ Pathology, and ${ }^{4}$ Biological Chemistry, Medical School, University of Ioannina, Ioannina, Greece

SUMMARY Fifty-one patients with autoimmune rheumatic diseases underwent biopsy of the labial minor salivary glands. These patients were divided according to histopathology of lip $\vec{N}$ biopsies into three groups (negative lip biopsy, $1+$ and $2+$ ). From all the patients stimulated ${ }^{\circ}$ parotid salivary flow was measured. In the saliva sodium, potassium, magnesium, $\alpha$-amylase, and $\vec{\iota}$ immunoglobulin levels (IgA, IgG, IgM) were measured. It is shown that patients with advanced chronic inflammatory disease of the minor salivary glands have decreased stimulated salivary flow. However, no statistically significant differences were observed in the biochemical markers\&o tested between the histopathological groups examined.

Key words: minor salivary glands, exocrine glands, lip biopsy, $\alpha$-amylase.

The major oral manifestations in patients with primary or secondary Sjögren's syndrome are mucosal dryness, atrophy, and accelerated dental decay. ${ }^{1}$ In an attempt to explain these oral manifestations studies of the salivary composition from these patients have been performed. The results for sodium, potassium, and immunoglobulin salivary content are conflicting. ${ }^{2-5}$

In the present study we approached the same questions by examining biochemical markers in stimulated parotid saliva from autoimmune rheumatic disease patients with or without histological findings in the minor salivary glands compatible with Sjögren's syndrome.

\section{Materials and methods}

We studied 51 patients with autoimmune rheumatic diseases. Sixteen patients (12 females and four females) had classical rheumatoid arthritis, ${ }^{6} 11$ patients (10 female and one male) had systemic lupus erythematosus, ${ }^{7}$ sixteen female patients had

Accepted for publication 10 January 1985.

Correspondence to Dr E B Tsianos, Department of Medicine, Medical School, University of Ioannina, 45332 Ioannina, Greece. primary Sjögren's syndiome, ${ }^{1}$ four female patients had mixed connective tissue disease, ${ }^{8}$ and four female patients had Raynaud's phenomenon.

All patients underwent minor salivary gland. biopsies regardless of subjective or objective mani- $\frac{0}{2}$ festations of xerostomia. The density of the in $-\frac{2}{-}$ flammatory infiltrations was examined and graded $\mathrm{B}$. according to Tarpley's criteria. ${ }^{9}$ From all these patients parotid salivary flow was measured with Carlson-Crittenden cups. Saliva was collected aftero lemon juice stimulation. The collected parotid salivas were centrifuged at $1500 \mathrm{rpm}$ for $10 \mathrm{~min}$. Theo supernatants were kept frozen at $-20^{\circ} \mathrm{C}$ until tested.

Sodium and potassium levels were assayed byo flame photometry (Corning photometer 435). Mag $N$ nesium was determined by the Magnesium Rapid Stat Kit (Lancer, Ireland). $\alpha$-Amylase activity waso measured by the 'Phadebas' method (Pharmaciâ AB, Uppsala, Sweden).${ }^{10}$ Immunoglobulin levels in saliva were measured by the single radial immuno-e? diffusion technique.

The concentrations of salivary electrolytesoํำ (sodium, potassium, magnesium), $\alpha$-amylase, and immunoglobulins (IgA, IgG, IgM) of the patients studied were expressed according to the five-minute flow rate. 
The statistical differences between the groups were evaluated by Student's $t$ test.

\section{Results}

Twenty-two of the 51 patients studied had normal minor salivary glands on labial biopsy. These constituted group 0 . Nine patients had labial biopsies graded as $\geqslant 1+$ group. The means of the flow rate, $\alpha$-amylase, sodium, potassium, magnesium, and immunoglobulin ( $\operatorname{IgA}, \operatorname{IgG}, \operatorname{IgM})$ levels in the five-minute flow rate of the saliva in the three groups of patients tested are shown in Table 1. The only statistical correlations found were the decreased parotid flow rate in patients with labial biopsies $\geqslant 2+$ versus patients with negative biopsies and between the mean secretion rates of $\alpha$-amylase in patients with $1+$ versus $\geqslant 2+$ labial biopsies. In addition it was seen that group $1+$ compared with group $\geqslant 2+$ had higher mean values in the secretion rates of sodium, potassium, magnesium, and IgA immunoglobulin. The salivary IgG and IgM immunoglobulins were not measurable by the method used.

\section{Discussion}

This study shows that there is a significant decrease of the salivary flow rate in patients with advanced inflammatory salivary glands disease; a finding which further substantiates previously reported observations. ${ }^{11}$ In the early inflammatory disease $(1+)$, however, the mean salivary flow rate did not differ from that of patients with normal minor salivary glands. This observation indicates that the salivary flow rate cannot be used as an early and sensitive indicator for the diagnosis of Sjögren's syndrome.

The other interesting observation in this study was that in the early inflammatory salivary glands disease $(1+)$ increased levels of the electrolytes and proteins tested were found compared with groups 0 and $\geqslant 2+$. This finding perhaps suggests that in the initial inflammatory stage the secretory epithelium is stimulated by the cellular inflammation or by lymphokines to produce more substances. Alternatively the increased levels in patients with mild inflammation can be attributed to the fact that the metaplastic epithelial cells that replace the normal ductal cells in these patients are not capable of reabsorbing these substances effectively. In the late inflammatory stage, however, the decrease of the salivary constituents can be attributed to the significant decrease of the secretory epithelium or to the replacement of these cells by non-functional collagen tissue.

Finally, we observed that the salivary $\operatorname{IgA}$ immunoglobulin did not correlate with the degree of inflammation of the minor salivary glands. From experiments in vitro and in vivo it is known that serum hypergammaglobulinaemia in patients with Sjögren's syndrome is attributed mostly to the excessive production of immunoglobulins due to the $B$ cells infiltration of the salivary or other exocrine glands. ${ }^{12}{ }^{13}$ Why the IgA immunoglobulin levels did not differ in patients with autoimmune rheumatic disease without inflammation of the minor salivary glands compared with mild or severe inflammatory changes is a very interesting question. We speculate that the immunoglobulins produced by the infiltrating cells are directed towards the circulation rather than the salivary excretions. This hypothesis is supported by our observation that explicit leakage of immunoglobulins IgG and IgM was not observed in the patients tested.

In conclusion sialochemistry of the stimulated parotid saliva cannot be used as a non-invasive adjunct for the diagnosis of chronic inflammatory disease of the salivary glands.

We wish to thank Ms E E Papanikolaou for excellent secretarial assistance.

\section{References}

1 Moutsopoulos H M. Chused T M. Mann D L, et al. Sjögren's syndrome (sicca syndrome): current issues. Ann Intern Med 1980: 92: 212-26.

Table 1 Biochemical values* between the histopathological groups in patients with autoimmune rheumatic diseases

\begin{tabular}{|c|c|c|c|c|c|c|c|}
\hline $\begin{array}{l}\text { Patient } \\
\text { group }\end{array}$ & $\begin{array}{l}\text { Patients } \\
\text { (n) }\end{array}$ & $\begin{array}{l}\text { Flow rate } \\
(\mathrm{ml} / 5 \mathrm{~min})\end{array}$ & $\begin{array}{l}\alpha-A \text { mylase } \\
(U / 5 \text { min })\end{array}$ & $\begin{array}{l}\mathrm{Na}^{+} \\
\left(\mathrm{mEq} \times 10^{-3} / 5 \mathrm{~min}\right)\end{array}$ & $\begin{array}{l}K^{+} \\
\left(\mathrm{mEq} \times 10^{-3} / 5 \mathrm{~min}\right)\end{array}$ & $\begin{array}{l}\mathrm{Mg}^{+} \\
\left(\mathrm{mEq} \times 10^{-3} / 5 \mathrm{~min}\right)\end{array}$ & $\begin{array}{l}\lg A \\
\left(\mathrm{mg} \times 10^{-2} / 5 \mathrm{~min}\right)\end{array}$ \\
\hline 0 & 22 & $1 \cdot 34 \pm 0 \cdot 78 \ddagger$ & $393 \cdot 1 \pm 362 \cdot 6$ & $21 \cdot 19 \pm 35 \cdot 54$ & $20 \cdot 81 \pm 14 \cdot 46$ & $0.056 \pm 0.089$ & $2 \cdot 13 \pm 1 \cdot 46$ \\
\hline $1+$ & 9 & $1 \cdot 28 \pm 1 \cdot 03$ & $635 \cdot 8 \pm 515 \cdot 4 \S$ & $31 \cdot 86 \pm 42 \cdot 12$ & $27 \cdot 34 \pm 25 \cdot 49$ & $0 \cdot 113 \pm 0 \cdot 268$ & $6 \cdot 87 \pm 9 \cdot 42$ \\
\hline$\geqslant 2+$ & 20 & $0.77 \pm 0.92$ & $247 \cdot 4 \pm 591 \cdot 7$ & $9 \cdot 9 \pm 17 \cdot 31$ & $13 \cdot 46 \pm 17 \cdot 41$ & $0.063 \pm 0.258$ & $1 \cdot 69 \pm 2 \cdot 1$ \\
\hline
\end{tabular}

*Values are mean $\pm S D$.

†According to lip biopsy.

$\ddagger p<0 \cdot 05$, group 0 versus $\geqslant 2+. \S p<0 \cdot 05$, group $1+$ versus $\geqslant 2+$. 
2 Mandel I D, Baurmash H. Sialochemistry in Sjögren's syndrome. Oral Surg 1976; 41: 182-7.

3 Ben-Aryeh H, Nahir M. Scharf Y, Gutman D, Laufer D, Szargel R. Sialochemistry of patients with rheumatoid arthritis. Oral Surg 1978; 45: 63-70.

4 Fischer C J, Wyshak G W, Weisberger D. Sjögren's syndrome. Electrophoretic and immunological observations on serum and salivary proteins of man. Arch Oral Biol 1968; 13: 257-70.

5 Herzberg S M. White C. Wolf R O. Characterization of salivary proteins in patients with Sjögren's syndrome. Oral Surg 1973; 36: $814-7$.

6 Ropes M W, Bennett G A, Cobb S. 1958 revision of diagnostic criteria for rheumatoid arthritis. Bull Rheum Dis 1958; 9: 175-6.

7 Cohen A S, Reynolds W E, Franklin E C, et al. Preliminary criteria for the classification of systemic lupus erythematosus. Bull Rheum Dis 1971; 21: 643-8.
8 Sharp G C, Irwin W S. Tan E M, et al. Mixed connective tissue disease, an apparently distinct rheumatoid disease syndrome $\frac{\omega}{\text {. }}$ associated with a specific antibody to an extractable nuclear antigen (ENA). Am J Med 1972; 52: 148-54.

9 Tarpley T M. Anderson L G. White C L. Minor salivary gland involvement in Sjögren's syndrome. Oral Surg 1974; 37: 64-74.

10 Ceska M. Brown B. Birath K. Ranges of $\alpha$-amylase activities in human serum and urine and correlations with some other $\alpha$ amylase methods. Clin Chim Acta 1969; 26: 445-53.

11 Rice D H. Advances in diagnosis and management of salivary gland diseases. West J Med 1984; 140: $238-49$.

12 Talal N Asofsky R. Lightbody P. Immunoglobulin synthesis by salivary gland lymphoid cells in Sjögren's syndrome. J Clin Invest 1970; 49: 49-56.

13 Lane H C, Callihan T R, Jaffe E S, Fauci A S, Moutsopoulos H M. Presence of intracytoplasmic IgG in the lymphocytic infiltrates of the minor salivary glands of patients with primary Sjögren's syndrome. Clin Exp Rheumatol 1983; 1: 237-40. 